JACEK BONAREK, Bizancjum $w$ dobie bitwy pod Mantzikert. Znaczenie zagrożenia seldżuckiego $w$ polityce bizantyńskiej $w$ XI wieku [Byzantium in the Times of the Battle of Mantzikert. Significance of the Seljuk Threat in the Byzantine Policy of $11^{\text {th }}$ Century], Towarzystwo Wydawnicze "Historia Iagellonica", Kraków 2011, pp. 296 [= Notos - Scripta Antiqua et Byzantina, 7].

The work, published as the $7^{\text {th }}$ part of the Notos - Scripta Antiqua et Byzantina series, published by Towarzystwo Wydawnicze "Byzantina Iagellonica" is intended to make the reader accustomed with the problems of home and foreign policy of the Byzantine Empire of the second part of $11^{\text {th }}$ century.

The author specializes in the history of Byzantine Empire. He has published numerous articles in specialist periodicals and a book about the image of the alien in John Skylitzes' Chronicle $^{1} \mathrm{He}$ is also a co-author of the history of Greece textbook ${ }^{2}$. It is not accidental that the title of the work recalls the battle of Mantzikert (1071), in which the Byzantine forces were defeated by the Turks while emperor Romanus IV Diogenes, commander of the army was taken prisoner. Jacek Bonarek has decided to present the influence of the Seljuk Turks on the internal situation and foreign policy of the Empire. It does not mean, however, that he has limited the scope of his work to Asia Minor only.

In the Introduction (p. 9-23) the author has concentrated on the current state of research and sources on which his own research was based. He has emphasized that although the sea of ink has been poured out to describe the battle itself, little has been written about the role it played in the history of Byzantium.

Chapter I (Byzantium in XI c., p. 25-50) depicts the panorama of the empire, following the death of emperor Basil II (1025). Particular emphasis has been put on the issue of succession, due to the fact that the emperor did not have a son and his co-reigning brother

1 Romajowie $i$ obcy $w$ Kronice Jana Skylitzesa. Identyfikacja etniczna Bizantyńczyków i ich stosunek do obcych $w$ świetle Kroniki Jana Skylitzesa, Toruń 2003.

2 S. Sprawski, S. Turlej, J. Bonarek, T. CzeKALSKI, Historia Grecji, Kraków 2005.
Constantine VIII did not care early enough to have any of his daughters married. All that led to a struggle for succession, in particular after the death of Theodora, the last representative of the Macedonian dynasty, in 1056. It coincided with other internal unrest such as a rebellion of the Bulgarians, under the command of Peter Delian and a series of mutinies and usurpations (of George Maniaces, Leon Tornices, Nicephorus Bryennius and Isaac Comnenus).

Chapter II (Byzantine Italy, p. 51-70) has been devoted to the unsuccessful defence of the remaining Byzantine territories on the Apennine Peninsula. Having drawn the complex situation in the south of Italy, the author has demonstrated the emperors' efforts to stop the Norman expansion, up to the year 1071 when the empire finally lost Bari.

Chapter III (The Pechenegs, p. 79-84), as the title says, contains information about complicated relations between the Pechenegs and the empire. It demonstrates regular raids of the Pechenegs on the imperial lands, which began during the reign of Constantine VIII, until 1091 when the success of Alexius I at Leburion borught peace back. Much attention has been paid to the unsuccessful attempt to win the Pechenegs against the Turks, thanks to getting the former settle down in Asia Minor, which ended up in a mutiny of some Pecheneg troops and defeats of the imperial army. In the chapter there is some place to present the circumstances and results of the Oghuz Turks onto the territory under the control of the Pechenegs.

Chapter IV (Byzantium and Its Neighbours in the $11^{\text {th }}$ Century, p. 95-114) has been devoted to the relations with the Serbs, Hungarians, Russians, states of the Caucasus and the Arabs. The author emphasizes the fact that in $10^{\text {th }}$ century the empire had to revise its policy due to the 
changes behind its external borders. Among the most important at that time he mentions dropping of Byzantine primacy by the Serbs, the increasing importance of the Hungarians and their pressure on imperial borders, growing aspirations of Jaroslav the Wise and new political situation in the Caucasus, resulting in the incorporation of some Caucasian countries into the empire. At the eastern borders new peoples appeared next to the old enemy, the Arabs. Among those new peoples, the Seljuks certainly played the key role.

The relations with the latter have been discussed in chapter V (Byzantium and the Seljuks, p. 115-146). Having briefly explaining the problem of the origin of Seljuk Turks, the author discusses their relations with the Ghaznavids and creation of the foundations of state during Toghrul Beg's reign. The following part of the chapter has been devoted to the early stage of Turkish expansion on the Byzantine territory, with a particular emphasis from the 1040s up to the death of Constantine X.

Thus having sketched the situation of the empire at the end of 1060s the author goes on to the figure of the ruler, inseparably connected with the battle of Mantzikert. He was chosen to be the consort by Eudocia Makrembolitissa, empress-widow of Constantine $\mathrm{X}$, due to his military achievements. The empire needed a commander who would put an end to enemy raids. The new emperor immediately went on to accomplish the expectations of his subjects, by taking up an offensive against the Seljuks. The military operations have been discussed in chapter VI (Romanus IV Diogenes' Campaigns, p. 147-176). Both the operations from the early years of Romanus's reign (1068-1070), as well as his last campaign, ended up in the defeat at Mantzikert have been presented here. An exhaustive part of the chapter has been dedicated to the battle itself (p. 167-176), in which the author has confronted historical sources and has made an attempt to reconstruct the course of events which led to a disaster.

Chapter VII (Civil Wars and the Loss of Asia Minor, p. 177-202), a continuation of the previous one, contains an analysis of the short- and long-term consequences of the lost battle. Among the most important there are the civil war between Romanus Diogenes, released from Turkish captivity and the dynasty of Ducas, as well as mutinies of mercenary troops (in particular those of Roussell of Bailleul), the result of which was further loss of territories and founding the Sultanate ar-Rum.

The chapters are followed by the conclusion (p. 204-216). Maps (p. 221-222) and indices (271-296) certainly facilitate the reading.

The work has been based on numerous sources (Byzantine and western ones) and multi-language literature (see the bibliography, p. 221-271). All that has led to some original, well-justified theses. The ones I am finding most important are as follows:

The Pechengs were as serious challenge as the Turks, at least to the 1060s. The defeat of the Byzatines at Preslav was more painful than that at Mantzikert. Thus the attempt to make them loyal subjects of the empire failed.

Turkish advancement was facilitated by the unrest in the empire (the usurpation of Isaac Comnenus is a good example).

From the military point of view the batthe of Mantzikert was not out of ordinary. It did not decisively change the balance of power between Byzantium and the Seljuks, although is confirmed the Turkish status in Armenia (p. 177). The empire did not suffer big losses in manpower, as most of the troops either fled the battlefield or withdrew with no significant loss. There no direct threat of Turkish invasion, for the struggle with the Fatimids was more important for Alp Arslan. Most decisive for the disastrous for the Byzantine Empire consequences of the defeat were home struggle and mutinous mercenary troops.

Turkish destructive raids were in no way a menace to the Byzantine rule in Asia Minor. The Byzantines were themselves responsible for the disaster (p. 203).

During the reign of the Comnens there was an opportunity to restore Byzantine supremacy of Asia Minor and to assimilate at least a part of Turkish newcomers (p. 207-209). It failed because of the crisis of the empire at the turn of $12^{\text {th }}$ and $13^{\text {th }}$ century. 
Particularly worth to be mentioned is the author's scientific workshop. The author is precise in detailed documentation of his theses. Nearly each sentence of the text has been supplemented by footnotes which not only refer to sources or other literature, but which are also a wealth of information on persons, events, terms, as well as on scientific debates about the problems discussed in the book. Paradoxically, it does not make the reading more difficult, just the opposite, in this way the main text was has become more "reading-friendly" also to indi- viduals who are not specialists. At the same time professional scholars will not be disappointed, thanks to the well-developed footnotes. Some of them are themselves mini-articles or encyclopaedic entries.

Unfortunately the English summary (p. 217-220) is very short, which should be regretted, as the book is certainly worth being made popular among non-Polish readers as well.

Teresa Wolińska (Łódź)

\section{Yuri Stoyanov, Defenders and Enemies of the True Cross: The Sasanian Conquest of Jerusalem in 614 and Byzantine Ideology of Anti-Persian Warfare, Verlag der Österreichischen Akademie der Wissenschaften, Wien 2011, pp. 103 [= Österreichischen Akademie der Wissenschaften, 819, Veröffentlichungen zur Iranistik, 61].}

Byzantinists have long argued about the nature of Heraclius' campaign against the Persians. In particular they have been interested in the question of ideological nature: was the idea of a religious war (crusade) present in the Byzantine political theories?

The reviewed book is composed of three parts and a bibliography. Chapter I (The Archaeology of the Persian Conquest of Jerusalem in 614 and the Written Sources, p. 11-24) has been devoted to presenting written sources about the scale of destruction made by Persian invaders in Palestine in 614, which has been confronted with the output of archeological research. The former draw a dark picture indeed. The Persian would exterminate a number of province's inhabitants and devastate the temples. Yet the in situ examination have not proven the scale of destruction. The research in particular temples of whose destruction we could read has revealed that in fact they did not suffer that much. This regards both the temples of Jerusalem and in its close vicinity (Church of Gethsemane, Church of St. Stephen, of Eleona, Church of Theotokos, of the Probatica), as well as the Church of the Holy Sepulchre and the churches in Zion. In none of them traces of any major reconstruction of the $7^{\text {th }}$ century have been discovered. It leads to a conclusion that while Palestine may have suffered due to demographic losses and deportations, there is no evidence of destruction of urban or church infrastructure.

In Chapter II (Christian Ideology of Warfare in the East Roman/Byzantine World and Sasanian Persia, p. 25-44) the author presents the process of forming of Christian attitude to war. $\mathrm{He}$ is interested in gradual moving from absolute condemnation of violence, through acceptance of a just war, up to creating the idea of a holy war. Much attention has been paid to the differences between East and West. He presents a scholarly debate that has been waged for years on the existence of the ideology of a holy war in the Byzantine Empire. Some scholars tend to perceive such a war in Heraclius' campaign again the Persians and in the operations of Nicephorus Phocas and John Tzimiskes against the Arabs. Others, e.g. V. Laurent tend to negate that idea in Byzantium (contrary to the West and the world of Islam). In the debate they have pointed out that some elements of a holy war never occurred in the Empire: e.g. no reli- 